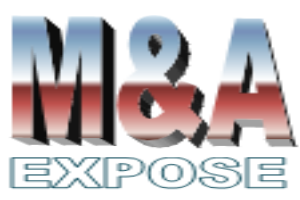

http://jurnal.usahid.ac.id/index .php/accounting
${ }^{1}$ Magister Sains Manajemen Universitas Indonesia anisiskamv961989@amail.com ${ }^{2}$ Magister Sains Manajemen Universitas Indonesia znzarara@gmail.com ${ }^{3}$ Magister Sains Manajemen Universitas Indonesia satrioutomo.dimas@gmail.com

\section{Analisis Hubungan Internasional Pasar Thailand dan Krisis Keuangan Thailand}

\author{
Ani Siska MY ${ }^{1}$, Azzara Nurfitri' ${ }^{2}$, Dimas Satrio Utomo ${ }^{3}$
}

Abstrak

Penelitian ini menganalisis penyebaran internasional krisis keuangan Thailand yang berdampak terhadap perekonomian Asia, Amerika Latin, dan Eropa Timur. Sampel dibagi menjadi tiga periode yaitu prakrisis, krisis, dan pascakrisis. Temuannya mengemukakan terdapat efek penularan akibat krisis keuangan Thailand 1997. Hal ini terlihat dari penurunan rata-rata return pasar selama periode krisis, peningkatan risiko (standar deviasi), serta peningkatan korelasi antarpasar. Pada periode non krisis, integrasi antarpasar Asia sangat terlihat dari adanya hubungan bidirectional antarpasar, atau informasi dan volatilitas di suatu pasar saling mempengaruhi return dan volatilitas di pasar lainnya. Hal tersebut disebabkan rentannya kondisi ekonomi Thailand saat itu dan meningkatnya risk averse investor terhadap pasar Thailand. Berbeda dengan hubungan antarpasar Asia, hubungan antara pasar Thailand dengan pasar Amerika Latin dan Eropa Timur cenderung lebih lemah. Oleh karena itu, disimpulkan bahwa krisis keuangan di Thailand pada tahun 1997 tidak berdampak langsung terhadap pasar Amerika Latin dan Eropa Timur.

Kata Kunci : krisis keuangan Thailand, bidirectional, return, volatilitas.

\section{Abstract}

This study analyzes the international spread of the Thai financial crisis which has an impact on the economies of Asia, Latin America and Eastern Europe. The sample is divided into three periods, namely pre-crisis, crisis, and post-crisis. His findings suggest there is a contagion effect due to the 1997 Thai financial crisis. This can be seen from the decrease in average market returns during the crisis period, increased risk (standard deviation), and an increase in inter-market correlations. In the non-crisis period, integration between Asian markets is evident from the existence of bidirectional relationships between markets, or information and volatility in one market affect the return and volatility in other markets. This was due to the vulnerability of the Thai economic conditions at the time and the increased risk averse of investors towards the Thai market. In contrast to relations between Asian markets, relations between the Thai market and Latin American and Eastern European markets tend to be weaker. Therefore, it was concluded that the financial crisis in Thailand in 1997 did not have a direct impact on the Latin American and Eastern European markets.

Keywords : Thai financial crisis, bidirectional, return, volatility. 
Analisis Hubungan Internasional Pasar Thailand ...

Ani Siska MY, Azzara Nurfitri \& Dimas Satrio Utomo

\section{PENDAHULUAN}

Penelitian Saleem (2009) menganalisa penyebaran internasional dari krisis keuangan Rusia pada tahun 1998 dengan model GARCH-BEKK yang dikemukakan Engle dan Kroner (1995). Dalam beberapa minggu sejak krisis Rusia dimulai, krisis tersebut hampir menurunkan hedge fund utama Amerika Serikat. Saleem (2009) menganalisis efek penularan krisis keuangan Rusia tahun 1998 dengan membagi menjadi tiga sub periode yaitu prakrisis, krisis, dan pascakrisis. Saleem (2009) menggunakan pasar Amerika Serikat, Uni Eropa, Asia, dan Emerging Europe karena negara-negara tersebut menjadi fokus pada era post-Soviet dan berperan penting dalam perdagangan dengan Rusia. Isu utama artikel tersebut adalah menguji hubungan internasional pasar saham Rusia dan transmisi internasional dari krisis keuangan Rusia 1998.

Krisis keuangan Asia 1998 merupakan salah satu fokus dalam dunia finansial. Krisis Keuangan Asia dimulai 2 Juli 1997 ketika pemerintah Thailand yang saat itu dibebani utang luar negeri yang besar, memutuskan untuk mengambangkan Baht setelah serangan yang dilakukan spekulan mata uang terhadap cadangan devisa negaranya. Pergeseran moneter itu bertujuan merangsang pendapatan ekspor namun strategi ini justru berefek penularan terhadap mata uang negara-negara Asia lainnya, termasuk Ringgit Malaysia, Peso Filipina, dan Rupiah Indonesia.Investor asing yang telah berinvestasi pada Asian Economic Miracle countries sejak satu dekade sebelumnya, kehilangan kepercayaan pada pasar Asia dan melepas mata uang serta aset-aset Asia secepat mungkin. Dalam beberapa bulan berikutnya, mata uang, pasar saham dan properti Thailand melemah.

Salah satu yang terdampak melemahnya kondisi ekonomi Thailand adalah Indonesia yang secara bertahap jatuh dalam krisis keuangan dan politik, serta Korea Selatan yang menghadapi tekanan balance of payments hingga mengalami default. Selain itu, beberapa pasar ekonomi di Amerika Latin dan Eropa Timur juga menghadapi tekanan balance of payments yang signifikan, mencerminkan spillover dari krisis Asia. Namun belum diketahui apakah efek spillover yang diterima regional Amerika Latin dan Eropa Timur merupakan dampak langsung krisis di Thailand atau dampak krisis Asia secara menyeluruh. Untuk itu, penelitian menganalisis keterkaitan pasar saham Thailand (dynamic spillover) dan contagion effect krisis Thailand tahun 1997 terhadap beberapa pasar tersebut, serta menganalisis hubungan langsung antara krisis Thailand dengan efek spillover yang diterima oleh Amerika Latin dan Eropa Timur (Graham, et.al., 2000).

\section{TINJAUAN PUSTAKA}

Proses ARCH (Auto Regressive Conditional Heteroscedasticity) dan GARCH (Generalized $A R C H$ ) dikenal dalam permodelan volatilitas return saham. Dalam memeriksa keterkaitan volatilitas antarnegara, pendekatan multivariate $G A R C H$ lebih dipilih daripada univariate. Namun model ini hanya dapat diestimasi dengan menerapkan beberapa batasan pada matriks conditional variance-covariancenya, seperti positive definiteness. Model awal Bollerslev et al. (1988) untuk memeriksa keterkaitan volatilitas antar negara gagal untuk menjamin positive definiteness matriks tersebut. Selain itu, batasan tersebut tidak memungkinkan cross equation conditional variance dan covariance memberi dampak satu sama lain. Masalah ini dapat dihindari oleh parameterisasi BEKK Engle dan Kroner (1995) 
dengan menggunakan bentuk kuadratik, sehingga sesuai dengan hipotesis korelasi konstan dan dapat digunakan dalam memeriksa volatilitas spillover antar pasar.

\section{METODE PENELITIAN}

Penelitian ini diawali dengan model bivariate GARCH yang mengakomodasi setiap return pasar dan pasar lain pada lag satu periode.

$$
\begin{aligned}
& \boldsymbol{r}_{t}=\boldsymbol{\mu}_{t}+\varepsilon_{t} \ldots \ldots . \\
& \mu_{t} \mid \Omega_{t-1} \sim \mathrm{N}\left(0, \boldsymbol{H}_{t}\right) .
\end{aligned}
$$

di mana $\mathbf{r}_{\mathrm{t}}$ adalah vektor $\mathrm{n} \times 1$ dari return harian pada waktu t untuk setiap pasar. Vektor $\mathrm{n} \times 1$ dari random error merepresentasikan inovasi untuk setiap pasar pada waktu $t$ dengan matriks conditional variance-covariance $\mathrm{nxn} \boldsymbol{H}_{t}$ yang sesuai. Informasi pasar yang tersedia pada waktu t-1 direpresentasikan oleh informasi pada $\Omega_{t-1}$. Mean spillovers pada dirinya sendiri dan antarpasar diukur dengan mengestimasi elemen matriks $\boldsymbol{\mu}_{t}$. Struktur multivariate memfasilitasi pengukuran efek inovasi pada rata-rata return harian dari satu seri terhadap return pada waktu sebelumnya (lag) dan return pasar lain pada waktu sebelumnya.

Matriks conditional covariance mengikuti Engle dan Kroner (1995) sebagai berikut:

$$
\boldsymbol{H}_{t}=\boldsymbol{C}_{0}^{\prime} \boldsymbol{C}_{0}+\boldsymbol{A}_{11}^{\prime} \varepsilon_{t-1} \varepsilon_{t-1}^{\prime} \boldsymbol{A}_{11}+\boldsymbol{G}_{11}^{\prime} \boldsymbol{H}_{t-1} \boldsymbol{G}_{11} \mathrm{q}
$$

di mana matriks parameter untuk persamaan varians didefinisikan sebagai $\boldsymbol{C}_{0}$, yang dibatasi menjadi lower triangular dan dua matriks yang tidak dibatasi $\boldsymbol{A}_{11}$ dan $\boldsymbol{G}_{11}$. Momen kedua tersebut dapat direpresentasikan sebagai berikut:

$$
\begin{gathered}
\boldsymbol{H}_{t}= \\
\boldsymbol{C}_{0}^{\prime} \boldsymbol{C}_{0}+\left[\begin{array}{ll}
a_{11} & a_{12} \\
a_{21} & a_{22}
\end{array}\right]^{\prime}\left[\begin{array}{cc}
\varepsilon_{1, t-1}^{2} & \varepsilon_{1, t-1,}, \varepsilon_{2, t-1} \\
\varepsilon_{1, t-1,}, \varepsilon_{2, t-1} & \varepsilon_{2, t-1}^{2}
\end{array}\right]\left[\begin{array}{ll}
a_{11} & a_{12} \\
a_{21} & a_{22}
\end{array}\right]+\left[\begin{array}{ll}
g_{11} & g_{12} \\
g_{21} & g_{22}
\end{array}\right]^{\prime} H_{t-1}\left[\begin{array}{ll}
g_{11} & g_{12} \\
g_{21} & g_{22}
\end{array}\right](4)
\end{gathered}
$$

Persamaan (4) tersebut untuk $\boldsymbol{H}_{\mathrm{t}}$ dapat diperluas dengan perkalian matriks berikut :

$$
\begin{aligned}
& h_{11, t}=h_{11, t}=c_{11}^{2}+a_{11}^{2} \varepsilon_{1, t-1}^{2}+2 a_{11} a_{12} \varepsilon_{1, t-1, \varepsilon_{2, t-1}}+a_{21}^{2} \varepsilon_{2, t-1}^{2}+g_{11}^{2} h_{11, t-1}+ \\
& 2 g_{11} g_{21} h_{12, t-1}+g_{21}^{2} h_{22, t-1} \\
& h_{12, t}=c_{11} c_{21}+a_{11} a_{12} \varepsilon_{1, t-1}^{2}+\left(a_{21} a_{12}+a_{11} a_{22}\right) \varepsilon_{1, t-1,} \varepsilon_{2, t-1}+a_{21} a_{22} \varepsilon_{2, t-1}^{2}+g_{11} g_{12} h_{11, t-1} \\
& +\left(g_{21} g_{12}+g_{11} g_{22}\right) h_{12, t-1}+g_{21} g_{22} h_{22, t-1} \\
& h_{22, t}=c_{21}^{2}+c_{22}^{2}+a_{12}^{2} \varepsilon_{1, t-1}^{2}+2 a_{12} a_{22} \varepsilon_{1, t-1,} \varepsilon_{2, t-1}+a_{22}^{2} \varepsilon_{2, t-1}^{2}+g_{12}^{2} h_{11, t-1}+ \\
& 2 g_{12} g_{22} h_{12, t-1}+g_{22}^{2} h_{22, t-1}
\end{aligned}
$$

Estimasi maximum likelihood dioptimisasi dengan algoritma Berndt, Hall, Hall dan Hausman $(\mathrm{BHHH})$. Untuk persamaan (5)-(7), didapat fungsi conditional log likelihood $L(\theta)$ untuk sampel dari T observasi sebagai berikut:

$$
\begin{aligned}
& L(\theta)=\sum_{t=1}^{T} l_{t}(\theta) \\
& l_{t}(\theta)=-\log 2 \pi-\frac{1}{2} \log \left|\boldsymbol{H}_{t}(\theta)\right|-\frac{1}{2} \varepsilon_{t}^{\prime}(\theta) \boldsymbol{H}_{t}^{-1}(\theta) \varepsilon_{t}(\theta)
\end{aligned}
$$


Analisis Hubungan Internasional Pasar Thailand ...

Ani Siska MY, Azzara Nurfitri \& Dimas Satrio Utomo

yang mana $\theta$ merupakan vektor dari seluruh parameter yang tidak diketahui. Maksimisasi numerical dari persamaan (8) dan (9) menghasilkan estimasi maximum likelihood dengan asymptotic standard error.

Untuk menguji hipotesis null bahwa model dispesifikasi dengan benar atau setara, dan noise term $\left(\boldsymbol{\mu}_{\mathrm{t}}\right)$ random, digunakan Ljung-Box $Q$ statistic yang diasumsikan asymptotically distributed ketika $\mathrm{x}^{2}$ dengan $(\mathrm{p}-\mathrm{k})$ degrees if freedom, di mana $k$ merupakan jumlah variabel penjelas. Sebagai uji robustness hipotesis bahwa pasar saham menunjukkan korelasi yang tinggi selama krisis keuangan (efek contagion) dan hubungan jangka panjang, digunakan teknik cross-market correlation dengan Johansen cointegration test. Untuk menganalisis efek penularan, periode data dibagi menjadi tiga periode mengikuti pembagian periode krisis Girard dan Rahman (2002), yaitu : periode prakrisis (1 Juli 1994 1 Juli 1997), periode krisis (2 Juli 1997 - 30 Juni 1998), dan periode pascakrisis (1 Juli 1998 - 31 Juli 2007).

Hasil pada tabel 1 menunjukkan penolakan terhadap hipotesis null bahwa return memiliki unit root dan mendukung hipotesis alternatif dari stasionaritas (pada nilai signifikansi 1 persen). Perkembangan indeks pasar modal yang ditunjukkan pada Gambar 1 menunjukkan non-stasioneritas.

Gambar 1. Perkembangan Indeks Pasar Saham Thailand, Indonesia, Korea, Eropa Timur, dan Amerika Latin (U.S. Dollar) Tahun 1994-2007

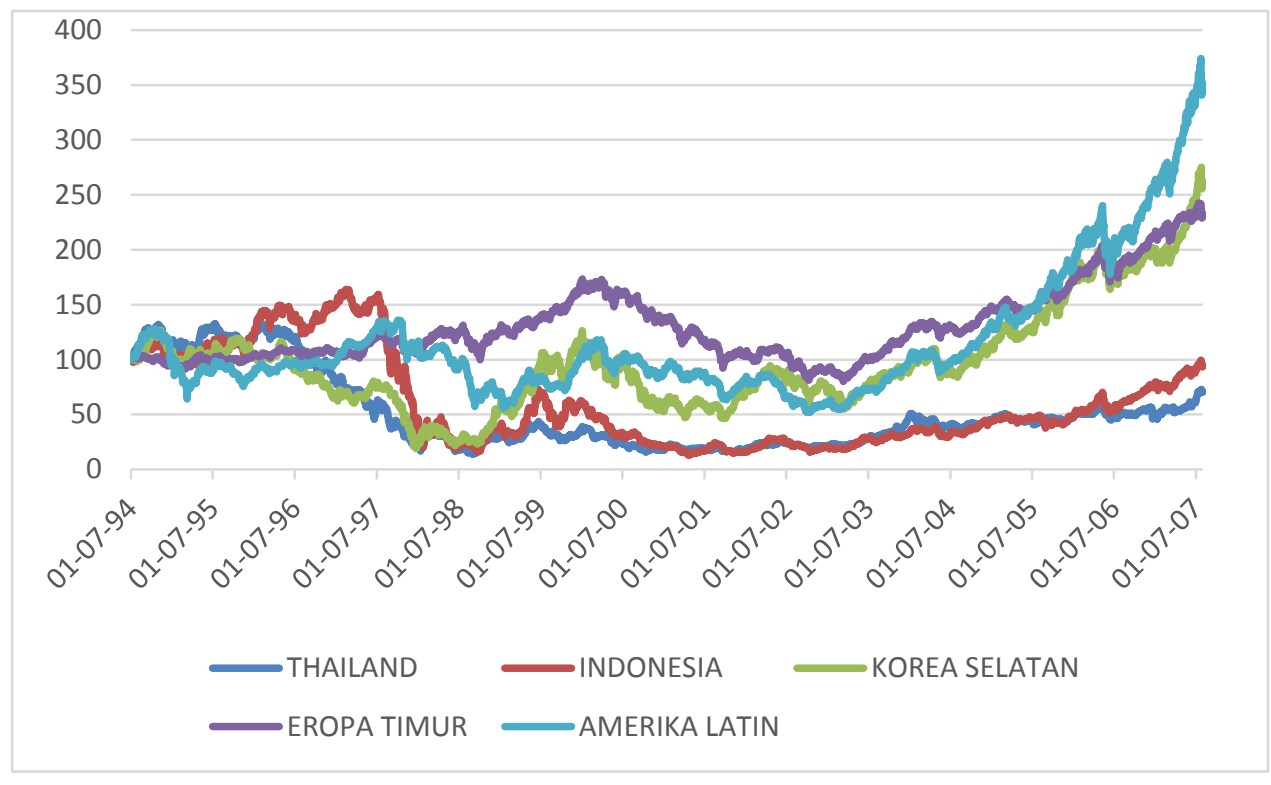

Pada Tabel 1 berikut terlihat bahwa pada periode krisis, kelima pasar mengalami penurunan return yang cukup drastis hingga mencapai negatif, yang mana efeknya paling besar dirasakan oleh daerah Asia yaitu Indonesia (-183,02\%), Thailand $(-106,02 \%)$, dan Korea Selatan $(-105,58 \%)$. Penurunan return yang cukup drastis ini diikuti dengan risiko (standar deviasi) yang meningkat, dengan risiko tertinggi ada pada pasar Korea Selatan $(81,79)$ dan Thailand $(64,7)$, tidak sesuai dengan teori investasi pada umumnya dimana return yang rendah seharusnya memiliki risiko yang rendah pula, seperti pada Indonesia dengan rata-rata return terendah juga diikuti dengan penuruan risiko $(6,78)$. 
Dari kelima pasar yang digunakan dalam penelitian ini, rata-rata return Eropa Timur mengalami penurunan yang paling kecil. Tetapi, penurunan risiko tersebut diikuti dengan peningkatan risiko. Begitu pula dengan Amerika Latin dengan rata-rata mean $-30,66 \%$. Berdasarkan Tabel 1 diketahui bahwa kelima pasar menunjukkan pola rata-rata return yang berbeda saat krisis jika dibandingkan dengan periode nonkrisis, serta peningkatan volatilitas cukup signifikan. Hal ini terjadi terutama pada pasar-pasar di Asia. Temuan ini juga sejalan dengan nilai skewness dan kurtosis yang tinggi pada setiap periodenya. Untuk menguji

Tabel 1

Ringkasan statistik deskriptif

\begin{tabular}{|c|c|c|c|c|c|}
\hline \multirow[t]{2}{*}{ Negara/Regional } & \multirow[t]{2}{*}{ Statistik } & Full Sampel & \multicolumn{3}{|l|}{ Sub-sampel } \\
\hline & & 1994-2007 & 1994-1997 & 1997-1998 & 1999-2007 \\
\hline \multirow[t]{9}{*}{ Thailand } & Mean & -2.479 & -18.397 & -106.019 & 14.138 \\
\hline & Std. dev. & 32.519 & 23.538 & 64.697 & 29.600 \\
\hline & Skewness & 0.336 & -0.085 & 0.701 & 0.125 \\
\hline & Kurtosis & 11.476 & 6.372 & 5.495 & 10.107 \\
\hline & JB & $10281.720^{*}$ & 373.688* & $88.725^{*}$ & 4993.987* \\
\hline & $\mathrm{ADF}$ & $-51.809 *$ & $-24.176 *$ & $-13.076^{*}$ & $-31.202^{*}$ \\
\hline & $\mathrm{LB}_{(24)}$ & $120.878^{*}$ & $50.730 *$ & 32.677 & $67.012 *$ \\
\hline & $\mathrm{LB}^{2}(24)$ & 1492.973* & 243.187* & $64.334 *$ & $380.172 *$ \\
\hline & ARCH-LM & 103.638* & $18.147^{*}$ & $9.324 *$ & $31.048 *$ \\
\hline \multirow[t]{9}{*}{ Indonesia } & Mean & -0.340 & 13.876 & -183.019 & 15.005 \\
\hline & Std. dev. & 42.067 & 16.288 & 6.784 & 35.173 \\
\hline & Skewness & -1.068 & -0.189 & -0.666 & 0.210 \\
\hline & Kurtosis & 29.736 & 7.353 & 8.416 & 11.156 \\
\hline & JB & $102303.40^{*}$ & $622.814 *$ & $337.021 *$ & $6586.551 *$ \\
\hline & ADF & $-26.048^{*}$ & $-21.962 *$ & $-14.366^{*}$ & $-42.743 *$ \\
\hline & $\mathrm{LB}_{(24)}$ & $202.257^{*}$ & $90.464 *$ & $40.214^{*}$ & $79.614^{*}$ \\
\hline & $\mathrm{LB}^{2}(24)$ & $2663.754 *$ & $74.076 *$ & $92.451 *$ & $488.469^{*}$ \\
\hline & ARCH-LM & $131.428^{*}$ & $11.520^{*}$ & $6.652 *$ & $18.455^{*}$ \\
\hline \multirow{9}{*}{ Korea Selatan } & Mean & 6.756 & -8.350 & $-105.575^{*}$ & $24.070^{*}$ \\
\hline & Std. dev. & 37.360 & 20.119 & 81.790 & 106.673 \\
\hline & Skewness & 0.298 & 0.043 & 0.591 & -0.014 \\
\hline & Kurtosis & 16.444 & 3.762 & 7.953 & 6.139 \\
\hline & JB & $25753.280^{*}$ & $19.175^{*}$ & $280.891 *$ & 973.367* \\
\hline & $\mathrm{ADF}$ & $-30.263^{*}$ & $-23.917^{*}$ & $-10.981 *$ & $-46.393^{*}$ \\
\hline & $\mathrm{LB}_{(24)}$ & 206.098* & 30.110 & $121.851 *$ & 30.040 \\
\hline & $\mathrm{LB}^{2}(24)$ & $4192.860^{*}$ & $96.004^{*}$ & $208.604^{*}$ & $494.739 *$ \\
\hline & ARCH-LM & $183.600^{*}$ & $4.531 *$ & 10.020 & $28.763^{*}$ \\
\hline \multirow{9}{*}{ Amerika Latin } & Mean & 8.848 & 7.629 & -30.661 & 13.585 \\
\hline & Std. dev. & 20.762 & 19.529 & 24.125 & 20.748 \\
\hline & Skewness & -0.610 & -0.336 & -1.782 & -0.468 \\
\hline & Kurtosis & 9.958 & 16.343 & 11.770 & 7.667 \\
\hline & JB & 7095.955* & $5822.848^{*}$ & 970.845* & $2237.833^{*}$ \\
\hline & ADF & $-38.946^{*}$ & $-21.796^{*}$ & $-13.749 *$ & $-40.113^{*}$ \\
\hline & $\mathrm{LB}_{(24)}$ & 195.613* & $98.201^{*}$ & $50.002 *$ & 118.693* \\
\hline & $\mathrm{LB}^{2}(24)$ & 1191.930* & $484.819 *$ & $54.688^{*}$ & 813.500* \\
\hline & ARCH-LM & $89.454 *$ & $29.245^{*}$ & $6.607 *$ & $54.227^{*}$ \\
\hline \multirow[t]{9}{*}{ Eropa Timur } & Mean & 5.914 & 5.523 & 2.636 & 6.402 \\
\hline & Std. dev. & 13.122 & 9.494 & 15.083 & 13.906 \\
\hline & Skewness & -0.277 & -0.083 & -0.209 & -0.297 \\
\hline & Kurtosis & 4.983 & 4.745 & 4.404 & 4.688 \\
\hline & JB & $602.850^{*}$ & $100.300^{*}$ & $23.241 *$ & $316.326^{*}$ \\
\hline & ADF & $-50.694 *$ & $-17.530^{*}$ & $-14.416^{*}$ & $-41.293^{*}$ \\
\hline & $\mathrm{LB}_{(24)}$ & $104.973^{*}$ & $36.686 *$ & 27.642 & $97.563^{*}$ \\
\hline & $\mathrm{LB}^{2}(24)$ & $1262.879 *$ & 179.808* & $49.963 *$ & $807.644^{*}$ \\
\hline & ARCH-LM & $61.130 *$ & $9.787 *$ & $3.874 *$ & $39.175^{*}$ \\
\hline
\end{tabular}

hipotesis null distribusi normal, dilakukan uji statistic Jarque-Bera dan menolak hipotesis null dari normalitas pada seluruh kasus.

Gambar 2 berikut menunjukkan adanya volatility clustering, yaitu perubahan yang besar cenderung diikuti oleh perubahan yang besar, dan perubahan kecil cenderung diikuti 
Analisis Hubungan Internasional Pasar Thailand ...

Ani Siska MY, Azzara Nurfitri \& Dimas Satrio Utomo

oleh perubahan kecil pada seluruh kasus. Dengan demikian, proses ARCH dapat diaplikasikan.

Gambar 2. Rangkaian Return Harian Indeks Pasar Amerika Latin, Eropa Timur, Indonesia, Korea Selatan, dan Thailand (U.S. Dollar) Tahun 1994-2007
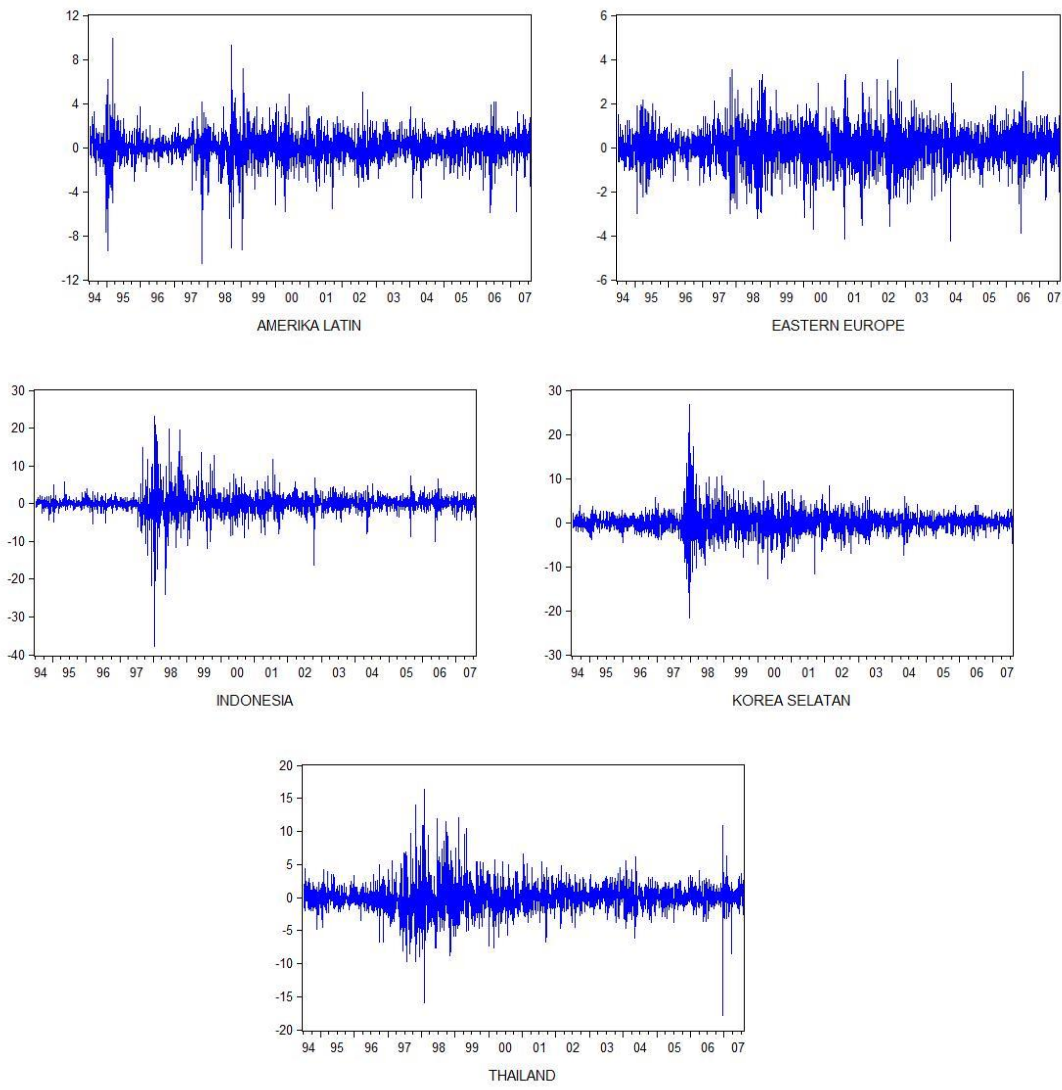

HASIL DAN PEMBAHASAN

Untuk menguji keterkaitan internasional antara pasar saham Thailand dengan empat model berpasangan (pair-wise model) diestimasi dengan menggunakan kerangka bivariate GARCH dengan representasi BEKK. Pasangan model terdiri dari Thailand-Indonesia, Thailand-Korea Selatan, Thailand-Amerika Latin, dan Thailand-Eropa Timur, menggunakan total return harian indeks yang dikalkulasi Datastream dari tanggal 1 Juli 1994 sampai 31 Juli 2007.

Matriks $\boldsymbol{\mu}_{\mathrm{t}}$ pada mean equation (persaman 1 ) yang ditangkap oleh parameter $\boldsymbol{c}_{\mathrm{ij}}$ pada tabel 2 melihat hubungan return antarnegara pada setiap pasangannya. Parameter diagonal $c_{11}$ dan $c_{22}$ pada seluruh pasangan secara statistik siginifikan, yang berarti bahwa return dari Thailand, Indonesia, Korea Selatan, Amerika Latin, dan Eropa Timur dipengaruhi oleh return pasar itu sendiri pada periode sebelumnya.

Matriks $\boldsymbol{A}$ dan $\boldsymbol{G}$ untuk menguji hasil estimasi dari variance-covariance yang timevarying, menggambarkan hubungan volatilitas sesuai dengan persamaan (4). Elemen diagonal pada matriks $\boldsymbol{A}$ menangkap efek $\mathrm{ARCH}$ pada pasar itu sendiri, sedangkan elemen 
diagonal matriks $G$ mengukur efek $\mathrm{GARCH}$ pada pasar itu sendiri. Pada tabel 2 terlihat bahwa parameter diagonal $\left(a_{11}, a_{22}\right.$, dan $\left.g_{11}, g_{22}\right)$ yang telah diestimasi seluruhnya signifikan secara statistik, mengindikasikan adanya proses $\mathrm{GARCH}(1,1)$ yang kuat menggerakkan conditional variance pada keempat pasang model indeks. Dengan kata lain, shock dan volatilitas pasar pada periode sebelumnya berdampak pada conditional variance dari indeks Thailand, Indonesia, Korea Selatan, Amerika Latin, dan Eropa Timur pada saat ini.

Table 2

Mean dan volatility spillover yang diestimasi dari model bivariate GARCH(1,1)-BEKK return harian indeks: 1 Juli 1994-31 Juli 2007

\begin{tabular}{|c|c|c|c|c|c|c|c|c|}
\hline \multirow[t]{2}{*}{ Parameter } & \multicolumn{2}{|c|}{$\begin{array}{l}\text { Thailand- } \\
\text { Indonesia }\end{array}$} & \multicolumn{2}{|c|}{$\begin{array}{c}\text { Thailand-Korea } \\
\text { Selatan }\end{array}$} & \multicolumn{2}{|c|}{$\begin{array}{c}\text { Thailand- } \\
\text { Amerika Latin }\end{array}$} & \multicolumn{2}{|c|}{$\begin{array}{c}\text { Thailand-Eropa } \\
\text { Timur }\end{array}$} \\
\hline & Koef. & S.E. & Koef. & S.E. & Koef. & S.E. & Koef. & S.E. \\
\hline \multicolumn{9}{|c|}{ Panel A: GARCH $(1,1)$ - Estimasi BEKK } \\
\hline A & $0.057^{*}$ & $(0.026)$ & $0.050^{*}$ & $(0.024)$ & $0.055^{*}$ & $(0.027)$ & 0.050 & $(0.026)$ \\
\hline B & $0.108^{*}$ & $(0.025)$ & $0.061^{*}$ & $(0.027)$ & $0.113^{*}$ & $(0.019)$ & $0.045^{*}$ & $(0.012)$ \\
\hline $\mathrm{C}_{11}$ & $0.322 *$ & $(0.010)$ & $0.311^{*}$ & $(0.013)$ & $0.282^{*}$ & $(0.011)$ & $0.320^{*}$ & $(0.013)$ \\
\hline $\mathrm{C}_{12}$ & $0.157^{*}$ & $(0.018)$ & 0.032 & $(0.020)$ & $0.126^{*}$ & $(0.024)$ & $0.036^{*}$ & $(0.012)$ \\
\hline $\mathrm{C}_{22}$ & $-0.161^{*}$ & $(0.013)$ & $-0.107^{*}$ & $(0.018)$ & $0.252^{*}$ & $(0.016)$ & $0.096^{*}$ & $(0.011)$ \\
\hline$A_{11}$ & $0.331^{*}$ & $(0.010)$ & $0.374^{*}$ & $(0.009)$ & $0.286^{*}$ & $(0.010)$ & $0.346^{*}$ & $(0.010)$ \\
\hline$A_{12}$ & $0.054^{*}$ & $(0.009)$ & $0.035^{*}$ & $(0.013)$ & 0.004 & $(0.008)$ & 0.006 & $(0.005)$ \\
\hline$A_{21}$ & $0.008^{*}$ & $(0.008)$ & $-0.068^{*}$ & (0.008) & $0.056^{*}$ & $(0.016)$ & -0.008 & $(0.026)$ \\
\hline$A_{22}$ & $0.330^{*}$ & $(0.008)$ & $0.205^{*}$ & (0.009) & $0.360^{*}$ & $(0.011)$ & $0.244^{*}$ & $(0.012)$ \\
\hline $\mathrm{G}_{11}$ & $0.934^{*}$ & $(0.003)$ & $0.920^{*}$ & $(0.003)$ & $0.951^{*}$ & $(0.003)$ & $0.929^{*}$ & $(0.003)$ \\
\hline $\mathrm{G}_{12}$ & $-0.027^{*}$ & $(0.003)$ & $-0.013^{*}$ & $(0.004)$ & -0.002 & $(0.003)$ & -0.002 & $(0.002)$ \\
\hline $\mathrm{G}_{21}$ & -0.002 & $(0.002)$ & $0.019^{*}$ & (0.003) & $-0.034^{*}$ & $(0.008)$ & 0.003 & $(0.009)$ \\
\hline $\mathrm{G}_{22}$ & $0.947^{*}$ & $(0.002)$ & $0.979 *$ & $(0.002)$ & $0.909^{*}$ & $(0.006)$ & $0.963^{*}$ & $(0.004)$ \\
\hline \multicolumn{9}{|c|}{ Panel B: Uji Diagnostik } \\
\hline LogLik & \multicolumn{2}{|c|}{-13595.470} & \multicolumn{2}{|c|}{-13589.261} & \multicolumn{2}{|c|}{-12131.064} & \multicolumn{2}{|c|}{-10644.376} \\
\hline $\mathrm{Lb}_{\mathrm{i}^{\mathrm{a}}}$ & \multicolumn{2}{|c|}{ 111.193* } & \multicolumn{2}{|c|}{$110.109 *$} & \multicolumn{2}{|c|}{$106.324^{*}$} & \multicolumn{2}{|c|}{$112.153^{*}$} \\
\hline $\mathrm{LB}_{j}$ & \multicolumn{2}{|l|}{$51.411^{*}$} & \multicolumn{2}{|l|}{$40.710^{*}$} & \multicolumn{2}{|c|}{$134.644^{*}$} & \multicolumn{2}{|c|}{ 53.839* } \\
\hline $\mathrm{LB}^{2}{ }_{\mathrm{i}}$ & \multicolumn{2}{|l|}{10.003} & \multicolumn{2}{|l|}{11.145} & \multicolumn{2}{|l|}{10.393} & \multicolumn{2}{|l|}{10.170} \\
\hline $\mathrm{LB}^{2}{ }_{\mathrm{j}}$ & \multicolumn{2}{|l|}{23.683} & \multicolumn{2}{|l|}{24.011} & \multicolumn{2}{|l|}{$40.367^{*}$} & \multicolumn{2}{|l|}{28.542} \\
\hline
\end{tabular}

\begin{tabular}{lccccc} 
& Amerika Latin & Eropa Timur & Indonesia & $\begin{array}{c}\text { Korea } \\
\text { Selatan }\end{array}$ & Thailand \\
\hline Panel C: Korelasi Antar Pasar (Cross-market) & & & & \\
Amerika Latin & 1 & 0.412 & 0.126 & 0.193 & 0.171 \\
Eropa Timur & 1 & 0.228 & 0.339 & 0.290 \\
Indonesia & & 1 & 0.202 & 0.346 \\
Korea Selatan & & & 1 & 0.297 \\
Thailand & & & & 1 \\
\hline
\end{tabular}

Elemen diagonal pada matriks $\boldsymbol{C}$ merepresentasikan mean equation. Sedangkan matriks $\boldsymbol{A}$ menangkap efek ARCH pada dirinya maupun antar pasar. Elemen diagonal pada matriks $\boldsymbol{G}$ mengukur efek GARCH pada dirinya maupun antar pasar. LB dan LB2 merepresentasikan Ljung-Box Q-statistic untuk standardized dan standardized squared residual

* Menunjukkan signifikansi pada tingkat 5\%

a Pada setiap pasangan. (i) Merepresentasikan pasar Thailand dan (j) pasar lain. 
Analisis Hubungan Internasional Pasar Thailand ...

Ani Siska MY, Azzara Nurfitri \& Dimas Satrio Utomo

Elemen off-diagonal matriks $\boldsymbol{A}$ dan $\boldsymbol{G}$ menangkap efek antarpasar seperti shock dan volatility spillovers antar empat pasang pasar. Dari tabel tersebut, dapat terlihat bahwa pada keseluruhan sampel terdapat korelasi dua arah (bidirectional) antara Thailand dengan Korea Selatan dan Indonesia (pasangan parameter off-diagonal, $a_{12}$ dan $a_{21}$, keduanya secara statistik signifikan). Hal ini mengindikasikan adanya hubungan yang kuat antara Thailand dengan Korea Selatan dan Indonesia. Selain itu didapatkan pula adanya hubungan satu arah (unidirectional) antara Thailand dengan Amerika Latin dengan arah Thailand dengan Amerika Latin (hanya parameter off diagonal $a_{12} y a n g$ signifikan secara statistik). Sedangkan pada hubungan Thailand dengan Eropa Timur, tidak ditemukan adanya hubungan selama periode studi.

Koefisien parameter $g_{12}$ dan $g_{21}$ menggambarkan volatility spillovers pada keempat pasang model. Kedua koefisien tersebut signifikan secara statistik pada pasangan Thailand - Korea Selatan yang berarti terdapat volatility spillovers dua arah. Koefisien parameter $g_{12}$ padaThailand-Indonesia signifikan secara statistik menandakan adanya volatility spillovers satu arah dari Thailand ke Indonesia, sedangkan pada Thailand-Amerika Latin, koefisien parameter $\mathrm{rg}_{21}$ signifikan secara statistik menandakan adanya volatility spillovers satu arah dari Amerika Latin ke Thailand. Antara Thailand dan Eropa Timur, kedua koefisien parameter tidak signifikan yang berarti tidak ada volatility spillovers antar keduanya. Hasil ini menunjukkan bahwa pasar Thailand berintegrasi dengan pasar lain, terutama pada pasar sampel yang digunakan pada studi tetapi derajat integrasinya agak lemah karena besaran dari koefisien estimasi cukup rendah.

Selanjutnya Tabel 3 berikut menunjukkan bahwa terdapat hubungan dua arah (bidirectional) antara Thailand dengan Indonesia pada periode prakrisis, dan hubungan satu arah (unidirectional) dari pasar Thailand ke pasar Korea Selatan dan dari pasar Eropa Timur ke pasar Thailand dalam hal return atau shock.menunjukkan dynamic shocks dan volatility spillovers pada keempat pasang model pada periode prakrisis. Sedangkan, Thailand dengan Amerika Latin tidak ditemukan adanya hubungan penyebaran informasi.

Untuk volatility spillover, ditemukan pula adanya hubungan dua arah (bidirectional) antara Thailand dengan Indonesia dan Thailand dengan Korea Selatan. Dengan demikian dapat dikatakan bahwa terdapat kecenderungan volatilitas pada pasar Thailand akan mempengaruhi volatilitas pada pasar Indonesia dan Korea Selatan, serta sebaliknya. Selain itu, ditemukan pula adanya hubungan satu arah (unidirectional) volatilitas dari pasar Thailand menuju pasar Eropa Timur, dan tidak ditemukan adanya volatility spillover antara Thailand dengan Amerika Latin. 
Table 3

Mean dan volatility spillover yang diestimasi dari model bivariate GARCH(1,1)-BEKK return harian indeks: 1 Juli 1994-1 Juli 1997

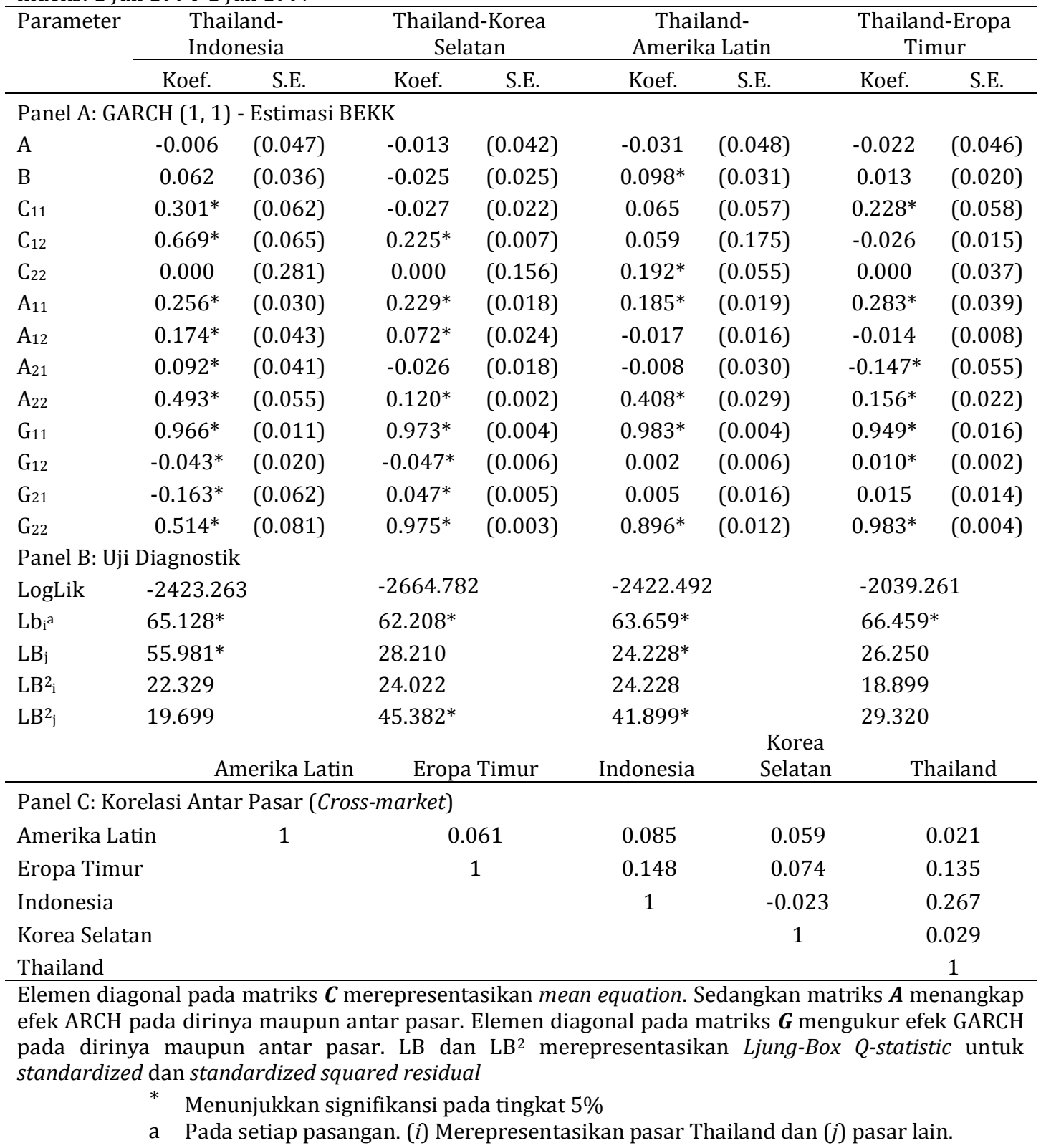

Pada hasil analisis yang dinyatakan pada Tabel 4 berikut pada bagian panel c, menunjukan bukti adanya peningkatan korelasi antar kedua negara sewaktu krisis dibandingkan dengan korelasi pasar antara kedua negara di saat sebelum krisis. Hasil ini diperkuat oleh hasil uji robustness Johansen cointegration antara kelima pasardengan melihat nilai Max-eigenvalue dan trace statistic. Seluruh nilai Max-eigenvalue dan trace statistic menunjukkan hasil yang signifikan secara statistik, sehingga dapat dikatakan bahwa hipotesis null yang menyatakan bahwa tidak ada kointegrasi antar pasar dapat ditolak. Dengan demikian pada periode krisis, kelima pasar saham memiliki kecenderungan jangka panjang untuk berkointegrasi dan berbagi keseimbangan (equilibrium) yang sama, atau dapat dikatakan, kelima pasar ini memiliki efek jangka panjang. 
Analisis Hubungan Internasional Pasar Thailand ...

Ani Siska MY, Azzara Nurfitri \& Dimas Satrio Utomo

Table 4

Mean dan volatility spillover yang diestimasi dari model bivariate GARCH(1,1)-BEKK return harian indeks: 2 Juli 1997-30 Juni 1998

\begin{tabular}{|c|c|c|c|c|c|c|c|c|}
\hline \multirow[t]{2}{*}{ Parameter } & \multicolumn{2}{|c|}{ Thailand-Indonesia } & \multicolumn{2}{|c|}{$\begin{array}{c}\text { Thailand-Korea } \\
\text { Selatan }\end{array}$} & \multicolumn{2}{|c|}{$\begin{array}{c}\text { Thailand-Amerika } \\
\text { Latin }\end{array}$} & \multicolumn{2}{|c|}{$\begin{array}{l}\text { Thailand-Eropa } \\
\text { Timur }\end{array}$} \\
\hline & Koef. & S.E. & Koef. & S.E. & Koef. & S.E. & Koef. & S.E. \\
\hline \multicolumn{9}{|c|}{ Panel A: GARCH $(1,1)$ - Estimasi BEKK } \\
\hline A & -0.392 & $(0.234)$ & $-0.617^{*}$ & $(0.232)$ & $-0.478^{*}$ & $(0.227)$ & -0.708 & $(0.197)$ \\
\hline B & -0.356 & $(0.352)$ & $-0.344^{*}$ & $(0.144)$ & 0.006 & $(0.075)$ & 0.034 & $(0.056)$ \\
\hline $\mathrm{C}_{11}$ & $0.110^{*}$ & $(0.302)$ & $0.771^{*}$ & $(0.240)$ & 0.059 & $(0.368)$ & 0.387 & $(0.420)$ \\
\hline $\mathrm{C}_{12}$ & -0.282 & $(0.700)$ & -0.235 & $(0.416)$ & $-0.680^{*}$ & $(0.082)$ & $-0.340^{*}$ & $(0.164)$ \\
\hline $\mathrm{C}_{22}$ & $0.341^{*}$ & $(0.297)$ & 0.262 & $(0.420)$ & 0.000 & $(0.316)$ & 0.000 & $(0.088)$ \\
\hline $\mathrm{A}_{11}$ & $0.341^{*}$ & $(0.070)$ & $0.150^{*}$ & $(0.054)$ & $0.290^{*}$ & $(0.065)$ & $0.392^{*}$ & $(0.058)$ \\
\hline $\mathrm{A}_{12}$ & 0.071 & $(0.100)$ & -0.031 & $(0.060)$ & 0.018 & $(0.019)$ & 0.005 & $(0.015)$ \\
\hline $\mathrm{A}_{21}$ & $-0.141^{*}$ & $(0.043)$ & $0.216^{*}$ & $(0.042)$ & $-0.445^{*}$ & $(0.186)$ & 0.180 & $(0.231)$ \\
\hline $\mathrm{A}_{22}$ & $0.434^{*}$ & $(0.059)$ & $0.515^{*}$ & $(0.058)$ & $0.610^{*}$ & $(0.080)$ & $0.258^{*}$ & $(0.055)$ \\
\hline $\mathrm{G}_{11}$ & $0.823^{*}$ & $(0.054)$ & $0.954^{*}$ & $(0.019)$ & $0.882^{*}$ & $(0.037)$ & $0.872^{*}$ & $(0.025)$ \\
\hline $\mathrm{G}_{12}$ & -0.009 & $(0.084)$ & 0.027 & $(0.030)$ & -0.022 & $(0.015)$ & -0.012 & $(0.009)$ \\
\hline $\mathrm{G}_{21}$ & $0.108^{*}$ & $(0.030)$ & $-0.076^{*}$ & $(0.014)$ & $0.654^{*}$ & $(0.156)$ & $0.476^{*}$ & $(0.149)$ \\
\hline $\mathrm{G}_{22}$ & $0.869^{*}$ & $(0.040)$ & $0.880^{*}$ & $(0.018)$ & $0.693^{*}$ & $(0.060)$ & $0.914^{*}$ & $(0.075)$ \\
\hline \multicolumn{9}{|c|}{ Panel B: Uji Diagnostik } \\
\hline LogLik & \multicolumn{2}{|l|}{-1529.031} & \multicolumn{2}{|l|}{-1434.772} & \multicolumn{2}{|l|}{-1164.932} & \multicolumn{2}{|c|}{-1054.162} \\
\hline$L b_{i}{ }^{a}$ & \multicolumn{2}{|l|}{31.858} & \multicolumn{2}{|l|}{30.997} & \multicolumn{2}{|l|}{33.009} & \multicolumn{2}{|l|}{31.834} \\
\hline $\mathrm{LB}_{\mathrm{j}}$ & \multicolumn{2}{|l|}{23.643} & \multicolumn{2}{|l|}{$49.960^{*}$} & \multicolumn{2}{|l|}{$38.474^{*}$} & \multicolumn{2}{|l|}{26.981} \\
\hline $\mathrm{LB}^{2}{ }_{\mathrm{i}}$ & \multicolumn{2}{|l|}{26.118} & \multicolumn{2}{|l|}{23.650} & \multicolumn{2}{|l|}{22.255} & \multicolumn{2}{|l|}{18.659} \\
\hline \multirow[t]{2}{*}{$\mathrm{LB}^{2}{ }_{\mathrm{j}}$} & \multirow{2}{*}{\multicolumn{2}{|c|}{17.548}} & \multicolumn{2}{|l|}{19.282} & 13.915 & & \multicolumn{2}{|l|}{31.921} \\
\hline & & & Eropa & Timur & Indonesia & Korea Selatan & & iland \\
\hline
\end{tabular}

Panel C: Korelasi Antar Pasar (Cross-market)

\begin{tabular}{|c|c|c|c|c|c|c|}
\hline Amerika Latin & & 0.515 & 0.140 & \multicolumn{2}{|c|}{0.230} & 0.204 \\
\hline Eropa Timur & & 1 & 0.291 & \multicolumn{2}{|c|}{0.167} & 0.342 \\
\hline Indonesia & & & 1 & \multicolumn{2}{|c|}{0.151} & 0.413 \\
\hline Korea Selatan & & & & \multicolumn{2}{|c|}{1} & 0.269 \\
\hline Thailand & & & & & & 1 \\
\hline \multirow{2}{*}{ No. of $\mathrm{CE}(\mathrm{s})$} & $\begin{array}{l}\text { Unrestricted } \\
\text { (trace) }\end{array}$ & cointegratior & n rank test & \multicolumn{3}{|c|}{$\begin{array}{l}\text { Unrestricted cointegration rank test } \\
\text { (maximum eigenvalue) }\end{array}$} \\
\hline & Eigenvalue & Statistik & Critical Value & Eigenvalue & Statistik & $\begin{array}{c}\text { Critical } \\
\text { Value }\end{array}$ \\
\hline \multicolumn{7}{|c|}{ Panel D: Johansen cointegration test } \\
\hline None $^{* *}(\mathrm{H} 0: \mathrm{r}=0, \mathrm{H} 1: \mathrm{r}=1)$ & 0.136 & 118.737 & 69.819 & 0.136 & 36.532 & 33.877 \\
\hline At most $1^{* *}(\mathrm{H} 0: \mathrm{r} \leq 1, \mathrm{H} 1: \mathrm{r}=2)$ & 0.112 & 82.205 & 47.856 & 0.112 & 29.511 & 27.584 \\
\hline At most $2^{* *}(\mathrm{H} 0: \mathrm{r} \leq 2, \mathrm{H} 1: \mathrm{r}=3)$ & 0.090 & 52.694 & 29.797 & 0.090 & 23.538 & 21.132 \\
\hline At most $3^{* *}(\mathrm{H} 0: \mathrm{r} \leq 3, \mathrm{H} 1: \mathrm{r}=4)$ & 0.063 & 29.156 & 15.495 & 0.063 & 16.290 & 14.265 \\
\hline At most $4^{* *}(\mathrm{H} 0: \mathrm{r} \leq 4, \mathrm{H} 1: \mathrm{r}=5)$ & 0.050 & 12.866 & 3.841 & 0.050 & 12.866 & 3.841 \\
\hline
\end{tabular}

Elemen diagonal pada matriks $\boldsymbol{C}$ merepresentasikan mean equation. Sedangkan matriks $\boldsymbol{A}$ menangkap efek ARCH pada dirinya maupun antar pasar. Elemen diagonal pada matriks $\boldsymbol{G}$ mengukur efek GARCH pada dirinya maupun antar pasar. LB dan LB2 merepresentasikan Ljung-Box Q-statistic untuk standardized dan standardized squared residual 
Hasil pengolahan data dengan model GARCH-BEKK selama periode krisis menunjukan bahwa sebagian besar shock dan volatility spillovers pada keempat pasang pasar bersifat satu arah (unidirectional) dari masing-masing pasar menuju Thailand, kecuali pada Eropa Timur hanya ditemukan volatility spillover dari Eropa Timur menuju Thailand, tetapi tidak ditemukan adanya shock spillover. Hal ini menunjukan pergerakan volatilitas pada masing-masing pasar akan berdampak pada pergerakan volatilitas pasar Thailand di waktu krisis, tetapi, pergerakan volatilitas di pasar Thailand sendiri tidak berdampak pada pasar lainnya.

Jika periode prakrisis pasar Thailand dapat berdampak terhadap pasar Indonesia dan Korea Selatan serta dapat berdampak volatility spillover terhadap pasar Eropa Timur, maka pada periode krisis, dampak tersebut tidak terlihat sehingga hubungannya berubah menjadi unidirectional dari masing-masing pasar ke pasar Thailand. Selain itu, sebelumnya pada periode prakrisis, antara pasar Thailand dan Amerika Latin tidak memiliki hubungan, sedangkan pada periode krisis, terdapat baik shock maupun volatility spillover dari Amerika Latin menuju Thailand. Sebaliknya, pada peride prakrisis, terdapat shock spillover dari pasar Eropa Timur menuju Thailand, sedangkan pada periode krisis, hubungan tersebut menghilang. Hasil pada penilaian parameter diagonal $\left(a_{11}, a_{22,} g_{11}\right.$ dan $\left.g_{22}\right)$ menunjukan bahwa rata-rata tingkat return pasar semua negara dan regional dipengaruhi oleh volatilitas pada periode sebelumnya.

Bagian akhir penelitian ini memeriksa adanya dampak perubahan pada shock dan volatilitas di pasar Thailand terhadap pasar negara dan regional lainnya pasca krisis.Jika sebelumnya pada periode krisis ditemukan bahwa spillover pada sebagian besar pasangan pasar bersifat unidirectional dari masing-masing pasar menuju pasar Thailand, pada periode ini beberapa pasar kembali kepada hubungan bidirectional seperti yang terjadi pada periode pre krisis. Hal ini terjadi pada shock spillover antara Thailand dengan Indonesia dan Korea Selatan serta volatility spillover antara Thailand dengan Korea yang kembali menjadi hubungan bidirectional. Pada Amerika Latin, dampak shock spillover dari Amerika Latin menuju Thailand tetap ada bahkan setelah periode krisis berakhir, serta jika sebelumnya volatility spillover mulai tampak dari Amerika Latin menuju Thailand pada periode krisis, pada periode setelahnya Thailand juga memberikan dampak volatility spillover terhadap pasar Amerika Latin sehingga hubungannya menjadi bidirectional. Sedangkan volatility spillover antara pasar Thailand dengan Indonesia dan Eropa Timur, yang sebelumnya bergerak dari masing-masing pasar menuju Thailand pada periode krisis, bergerak dalam arah yang sebaliknya pada periode pasca krisis. Jadi dapat dikatakan pada periode ini, volatilitas pada pasar Thailand mempengaruhi pasar Indonesia dan Eropa Timur. Menghilangnya dampak shock spillover antara Thailand dengan Eropa Timur dari periode prakrisis menuju periode krisis, bertahan hingga periode pasca krisis, atau dapat dikatakan informasi pada kedua pasar tidak lagi saling mempengaruhi satu sama lain.

Penemuan lain yang diperlihatkan pada tabel 5 adalah bahwa imbal hasil pasar pada semua negara dan regional dipengaruhi oleh masing-masing shock dan volatilitynya sendiri. Hasil ini sejalan dengan penelitian Saleem (2009) yang menjadi salah satu rujukan dalam penelitian ini. Pada mean equation menunjukan bahwa imbal hasil seluruh pasar dipengaruhi oleh tingkat imbal hasilnya sendiri. 
Analisis Hubungan Internasional Pasar Thailand ...

Ani Siska MY, Azzara Nurfitri \& Dimas Satrio Utomo

Table 5

Mean dan volatility spillover yang diestimasi dari model bivariate GARCH(1,1)-BEKK return harian indeks: 1 Juli 1998 - 31 Juli 2007

\begin{tabular}{|c|c|c|c|c|c|c|c|c|}
\hline \multirow[t]{2}{*}{ Parameter } & \multicolumn{2}{|c|}{$\begin{array}{l}\text { Thailand- } \\
\text { Indonesia }\end{array}$} & \multicolumn{2}{|c|}{$\begin{array}{l}\text { Thailand-Korea } \\
\text { Selatan }\end{array}$} & \multicolumn{2}{|c|}{$\begin{array}{l}\text { Thailand-Amerika } \\
\text { Latin }\end{array}$} & \multicolumn{2}{|c|}{$\begin{array}{l}\text { Thailand-Eropa } \\
\text { Timur }\end{array}$} \\
\hline & Koef. & S.E. & Koef. & S.E. & Koef. & S.E. & Koef. & S.E. \\
\hline \multicolumn{9}{|c|}{ Panel A: GARCH $(1,1)$ - Estimasi BEKK } \\
\hline A & $0.100^{*}$ & $(0.031)$ & $0.107^{*}$ & $(0.028)$ & $0.115^{*}$ & $(0.033)$ & $0.101^{*}$ & $(0.032)$ \\
\hline B & $0.147^{*}$ & $(0.034)$ & $0.111^{*}$ & $(0.034)$ & $0.131^{*}$ & $(0.025)$ & $0.062^{*}$ & $(0.016)$ \\
\hline $\mathrm{C}_{11}$ & $0.454^{*}$ & $(0.018)$ & $0.424^{*}$ & $(0.023)$ & $0.423^{*}$ & $(0.028)$ & $0.420^{*}$ & $(0.019)$ \\
\hline $\mathrm{C}_{12}$ & $0.222^{*}$ & $(0.031)$ & $0.057^{*}$ & $(0.028)$ & $0.202^{*}$ & $(0.040)$ & $0.081^{*}$ & $(0.018)$ \\
\hline $\mathrm{C}_{22}$ & $0.206^{*}$ & $(0.021)$ & 0.046 & $(0.039)$ & $0.233^{*}$ & $(0.036)$ & $0.124^{*}$ & $(0.017)$ \\
\hline$A_{11}$ & $0.368^{*}$ & $(0.014)$ & $0.453^{*}$ & $(0.012)$ & $0.365^{*}$ & $(0.014)$ & $0.371^{*}$ & $(0.015)$ \\
\hline $\mathrm{A}_{12}$ & $0.055^{*}$ & $(0.015)$ & $0.074^{*}$ & $(0.020)$ & -0.016 & $(0.013)$ & 0.017 & $(0.010)$ \\
\hline $\mathrm{A}_{21}$ & $0.028^{*}$ & $(0.014)$ & $-0.117^{*}$ & $(0.010)$ & $0.127^{*}$ & $(0.020)$ & 0.013 & $(0.032)$ \\
\hline $\mathrm{A}_{22}$ & $0.309^{*}$ & $(0.010)$ & $0.132^{*}$ & $(0.012)$ & $0.289 *$ & $(0.014)$ & $0.253^{*}$ & $(0.016)$ \\
\hline $\mathrm{G}_{11}$ & $0.902^{*}$ & $(0.005)$ & $0.875^{*}$ & $(0.005)$ & $0.914^{*}$ & $(0.006)$ & $0.909^{*}$ & $(0.005)$ \\
\hline $\mathrm{G}_{12}$ & $-0.042 *$ & $(0.006)$ & $-0.029 *$ & $(0.007)$ & $0.037^{*}$ & $(0.006)$ & $-0.009 *$ & $(0.004)$ \\
\hline $\mathrm{G}_{21}$ & -0.005 & $(0.005)$ & $0.031^{*}$ & $(0.004)$ & $-0.137^{*}$ & $(0.012)$ & -0.009 & $(0.013)$ \\
\hline $\mathrm{G}_{22}$ & $0.951^{*}$ & $(0.004)$ & $0.994^{*}$ & $(0.002)$ & $0.916^{*}$ & $(0.008)$ & $0.956^{*}$ & $(0.007)$ \\
\hline \multicolumn{9}{|c|}{ Panel B: Uji Diagnostik } \\
\hline LogLik & \multicolumn{2}{|c|}{-9519.749} & \multicolumn{2}{|c|}{-9417.681} & \multicolumn{2}{|l|}{-8464.888} & \multicolumn{2}{|c|}{-7494.951} \\
\hline $\mathrm{Lb}_{\mathrm{i}}^{\mathrm{a}}$ & \multicolumn{2}{|l|}{$67.627^{*}$} & \multicolumn{2}{|l|}{$64.758^{*}$} & \multicolumn{2}{|l|}{$62.869 *$} & \multicolumn{2}{|c|}{$66.653^{*}$} \\
\hline $\mathrm{LB}_{\mathrm{j}}$ & \multicolumn{2}{|l|}{28.233} & \multicolumn{2}{|l|}{23.194} & \multicolumn{2}{|l|}{$79.894^{*}$} & \multicolumn{2}{|c|}{55,285} \\
\hline $\mathrm{LB}^{2}{ }_{\mathrm{i}}$ & \multicolumn{2}{|l|}{7.595} & \multicolumn{2}{|l|}{9.172} & \multicolumn{2}{|l|}{8.314} & \multicolumn{2}{|l|}{7.633} \\
\hline \multirow[t]{2}{*}{$\mathrm{LB}^{2}{ }_{\mathrm{j}}$} & \multicolumn{2}{|l|}{12.822} & \multicolumn{2}{|l|}{27.992} & $37.899 *$ & & \multicolumn{2}{|c|}{55.285} \\
\hline & \multicolumn{2}{|c|}{ Amerika Latin } & \multicolumn{2}{|c|}{ Eropa Timur } & Indonesia & $\begin{array}{l}\text { Korea } \\
\text { Selatan }\end{array}$ & \multicolumn{2}{|c|}{ Thailand } \\
\hline Panel C: Ko & elasi Antar & Pasar (Cros & market) & & & & & \\
\hline Amerika La & & 1 & & 176 & 0.147 & 0.222 & & 0.205 \\
\hline Eropa Timı & & & & 1 & 0.252 & 0.452 & & 0.319 \\
\hline Indonesia & & & & & 1 & 0.259 & & 0.319 \\
\hline Korea Selat & & & & & & 1 & & 0.354 \\
\hline Thailand & & & & & & & & 1 \\
\hline
\end{tabular}

Elemen diagonal pada matriks $C$ merepresentasikan mean equation. Sedangkan matriks $A$ menangkap efek ARCH pada dirinya maupun antar pasar. Elemen diagonal pada matriks $\boldsymbol{G}$ mengukur efek GARCH pada dirinya maupun antar pasar. LB dan LB2 merepresentasikan Ljung-Box Q-statistic untuk standardized dan standardized squared residual

* Menunjukkan signifikansi pada tingkat $5 \%$

a Pada setiap pasangan. (i) Merepresentasikan pasar Thailand dan (j) pasar lain. 
Untuk seluruh periode, terlihat adanya hubungan shock spillover dua arah pada pasar Thailand dengan pasar Indonesia dan Korea. Wang dan Liu (2016) mengatakan bahwa, di antara faktor-faktor yang menyebabkan efek spillover, wilayah geografis menjadi hal yang penting. Hal ini dikarenakan investor akan mengalokasikan asetnya pada pasar yang dapat menurunkan biaya transaksinya. Pasar keuangan Asia sendiri telah menerapkan perubahan kebijakan yang dapat memfasilitasi investasi antarnegara. Meningkatnya kebijakan liberalisasi ini seringkali dapat meningkatkan integrasi antar pasar (Jebran \& lqbal, 2016), sehingga seharunya efek spillover antar pasar juga meningkat. Miyakoshi (2003) juga menyatakan bahwa efek regional lebih kuat daripada pasar dunia terhadap regional Asia. Selain dampak spillover, efek penularan (contagion) atau peningkatan kekuatan keterkaitan antar pasar selama periode krisis, juga merupakan isu yang penting.

Untuk melihat efek penularan (contagion) dari krisis keuangan Thailand 1997, periode sampel dibagi menjadi tiga. Pada periode prakrisis, terlihat bahwa Thailand memiliki hubungan dua arah (bidirectional) dengan Indonesia dan Korea Selatan pada shock spillovernya. Kemudian, hubungan ini berubah menjadi satu arah dari Indonesia dan Korea Selatan menuju Thailand, dan kembali menjadi dua arah pasca krisis. Temuan ini sesuai dengan Yang et al. (2003) yang menyatakan bahwa pada periode pra dan pasca krisis, Indonesia dan Korea Selatan merespon shock dari Thailand, tetapi tidak pada saat krisis.

Wang dan Liu (2016) menemukan bahwa pasar Thailand merupakan pasar yang paling rentan di Asia, dan menerima banyak dampak spillover dari pasar lainnya, serta hanya memberikan sekitar 2 persen dampak spillover terhadap pasar Asia selama periode krisis. In et al. (2001) dengan data tahun 1997 - 1998 sesuai dengan periode krisis yang digunakan dalam penelitian ini, juga menyatakan bahwa rata-rata return di Thailand dipengaruhi oleh return dirinya sendiri dan return Korea periode sebelumnya. Volatilitas Thailand juga dipengaruhi oleh volatilitasnya sendiri di periode sebelumnya, serta volatilitas di pasar Korea, sedangkan volatilitas di pasar Thailand tidak mempengaruhi volatilitas pasar Korea.

Rentannya Thailand selama periode krisis ini disebabkan oleh hilangnya kepercayaan investor atau meningkatnya risk aversion investor terhadap Thailand akibat kondisi ekonominya dan nilai mata uangnya yang menurun tajam secara tiba-tiba hingga akhirnya Thailand meminta bantuan International Monetary Funds (IMF) untuk menstabilkan ekonominya. Penurunan ekonomi Thailand ini juga berdampak pada Indonesia karena investor asing menganggap ekonomi Indonesia sama dengan Thailand (Jungjaturapit, 1998). Jadi dipersepsikan bahwa kemungkinan informasi yang berasal dari Indonesia juga akan menyebabkan perubahan volatilitas di Thailand selama periode krisis.

Kembalinya hubungan bidirectional pasca krisis sesuai dengan Brailsford et al.(2006) menyatakan bahwa sebagian besar pasar Asia menunjukkan hubungan dan integrasi yang signifikan setelah krisis. Wang dan Liu (2016) juga menyatakan bahwa integrasi yang terjadi antar pasar Asia bersifat dinamis. Seiring dengan berjalannya waktu, pasar di Asia menjadi lebih terintegrasi. Dalam pasar Asia, dampak spillover terkuat ada pada pasar Asia Tenggara. Hal ini dikarenakan adanya hubungan intraregional pada pasar Asia Tenggara dan seluruhnya bergantung pada external trade. Menurut $\mathrm{Ng}$ (2000), trading internasional dapat meningkatkan korelasi konsumsi dan siklus bisnis antarnegara, sehingga meningkatkan tingkat integrasi ekonomi dan finansial.

In et al. (2001) juga menemukan bahwa pasar menjadi lebih saling terkait dan terintegrasi selama periode krisis Asia, sehingga pasar tidak hanya bereaksi pada informasi 
Analisis Hubungan Internasional Pasar Thailand ...

Ani Siska MY, Azzara Nurfitri \& Dimas Satrio Utomo

lokal, tetapi juga informasi yang berasal dari pasar lainnya. Thailand selama periode krisis menunjukkan keterkaitan yang lebih besar dengan Korea dan Hong Kong. Hal ini disebabkan Hong Kong berperan penting dalam transmisi volatilitas di pasar Asia lainnya.

Berbeda dengan pasar Asia, hubungan antara pasar Thailand dengan Amerika Latin dan Eropa Timur cenderung lemah. Brailsford et al. (2006) menyatakan bahwa sebelum memasuki periode krisis, pasar Asia terpisah dari pasar global. Tetapi, rentannya kondisi pasar Thailand selama krisis (Wang \& Liu, 2016) dapat menyebabkan pasar di luar pasar Asia ini memberikan dampak satu arah terhadap pasar Thailand. Letak geografis dan kebijakan liberalisasi yang berbeda seperti yang telah dijelaskan sebelumnya juga dapat mempengaruhi hubungan antar dua pasar saham ini.

Pada panel $\mathrm{C}$ tabel 2 sampai tabel 5 terdapat koefisien korelasi antar pasar. Koefisien korelasi antara Thailand dengan pasar Asia lebih besar daripada koefisien korelasinya dengan Amerika Latin dan Eropa Timur. Chatterjee et.al ( 2003 ) mengemukakan bahwa korelasi yang kuat di antara pasar Thailand dengan pasar Asia dikarenakan adanya market oriented reforms, restructuring, dan globalisasi pada tahun 1990-an yang membuat pasar di negara-negara Pacific-Basin antaranya Thailand, Indonesia, dan Korea Selatan memiliki return of trend yang serupa.

\section{KESIMPULAN}

Penelitian ini menggunakan data pasar Thailand dan krisis keuangan Thailand 1997, dan mengaitkannya dengan pasar saham Indonesia, Korea Selatan, Amerika Latin dan Eropa Timur. Dengan model GARCH-BEKK, diestimasi model four pair-wise atau empat pasang dengan menggunakan total return harian index. Hasil analisis menunjukkan bahwa terdapat hubungan langsung antara Thailand dengan pasar lain, baik dalam return maupun volatility tetapi keterkaitannya bersifat lemah, yaitu pasar Thailand hanya berintegrasi parsial dengan pasar dunia.

Secara keseluruhan ditemukan adanya shock maupun volatility spillover antara pasar Thailand dengan pasar Indonesia dan Korea Selatan yang dapat disebabkan oleh lokasi geografi yang berdekatan. Lokasi geografi ini dapat mempengaruhi investor dalam mengambil keputusan. Saat Thailand mengalami penurunan ekonomi, Indonesia terimbas dampaknya karena dianggap memiliki perekonomian yang mirip. Selain itu, kebijakan liberalisasi yang diterapkan di Asia juga meningkatkan integrasi pasar di Asia. Adapun pasar Eropa Timur dan Amerika Latin yang tidak berada dalam lokasi geografis yang sama memberikan dan menerima dampak yang kurang signifikan dari pasar Thailand.

Temuan penelitian ini menunjukkan bahwa terdapat efek penularan akibat krisis keuangan Thailand 1997. Hal ini dapat terlihat dari rata-rata return pasar lain yang menurun selama periode krisis serta risiko (standar deviasi) yang meningkat, serta meningkatnya korelasi antarpasar. Pada periode non krisis, integrasi antarpasar Asia ini sangat terlihat dari adanya hubungan bidirectional antarpasar, atau informasi dan volatilitas di suatu pasar saling mempengaruhi return dan volatilitas di pasar lainnya. Tetapi, dalam periode krisis, dampak dari pasar Thailand terhadap pasar lainnya menghilang. Hal tersebut dikarenakan oleh rentannya kondisi ekonomi Thailand saat itu dan meningkatnya risk averse investor terhadap pasar Thailand. Berbeda dengan hubungan antarpasar Asia, hubungan antara pasar Thailand dengan pasar Amerika Latin dan Eropa Timur tampak lebih lemah. Hal ini 
disebabkan terpisahnya pasar Asia dengan pasar global pada periode prakrisis, serta dimungkinkan karena perbedaan lokasi geografis dan kebijakan liberalisasi antara pasar Thailand dengan pasar Amerika Latin dan Eropa Timur. Oleh karena itu, disimpulkan bahwa krisis keuangan di Thailand pada tahun 1997 tidak berdampak langsung terhadap pasar Amerika Latin dan Eropa Timur. Akan tetapi, berkembangnya krisis keuangan Thailand 1997 menjadi krisis keuangan Asia kemungkinan dapat memberikan dampak spillover terhadap kedua pasar tersebut.

\section{DAFTAR PUSTAKA}

Brailsford, T. J., Penm, J. H. W., \& Terrell, R. D. (2006). an Analysis of Asian Market Integration Pre- and Post-Crisis. International Journal of Theoretical and Applied Finance, 9(4), 483-501. https://doi.org/10.1142/S0219024906003718

Chatterjee, Sayan., Wiseman, Robert M., Fiegenbaum., \& Devers, Cynthia E. (2003). Integrating Behavioral and Economic Concepts of Risk into Strategic Management: the Twain Shall Meet. Long Range Planning. 36, 61-79.

Engle, R. F. and K. F. Kroner (1995). Multivariate simultaneous generalized ARCH. Econometric Theory 11, 122-150.

Girard, E. C., \& Rahman, H. (2002). The Effect of the Asian Financial Crisis on Stock Returns, Volatility and Market Integration in the Region. Studies in Economics and Finance, 20(1), 51-75. https://doi.org/10.1108/eb028759

Graham, R., King, R., \& Bailes, J. (2000). The Value Relevance of Accounting Information During a Financial Crisis: Thailand and The Decline in the Value of the Bath, Journal of International Financial. 11,84-107.

In, F., Kim, S., Yoon, J. H., \& Viney, C. (2001). Dynamic interdependence and volatility transmission of Asian stock markets: Evidence from the Asian crisis. International Review of Financial Analysis, 10(1), 87-96. https://doi.org/10.1016/S10575219(00)00045-4

Jebran, K., \& lqbal, A. (2016). Examining volatility spillover between Asian countries' stock markets. China Finance and Economic Review, 4(1), 6. https://doi.org/10.1186/s40589016-0031-1

Jungjaturapit, K. (1998). Has Thailand Learned from the Asian Crisis of 1997 ?

Miyakoshi, T. (2003). Spillovers of stock return volatility to Asian equity markets from Japan and the US. Journal of International Financial Markets, Institutions and Money, 13(4), 383-399. https://doi.org/10.1016/S1042-4431(03)00015-5

$\mathrm{Ng}$, A. (2000). Volatility spillover effects from Japan and the US to the Pacific-Basin. Journal of International Money and Finance, 19(2), 207-233. https://doi.org/10.1016/S02615606(00)00006-1

Saleem, K. (2009). International linkage of the Russian market and the Russian financial crisis: A multivariate GARCH analysis. Research in International Business and Finance, 23(3), 243-256. https://doi.org/10.1016/j.ribaf.2008.09.003

Wang, Y., \& Liu, L. (2016). Spillover effect in Asian financial markets: A VAR-structural GARCH analysis Yu Wang Lei Liu Article. China Finance Review International, 6(22), 208-227. https://doi.org/10.1108/CFRI-06-2015-0056

Yang, J., Kolari, J. W., \& Min, I. (2003). Stock market integration and financial crises: The case of Asia. Applied Financial Economics, 13(7), 477-486. https://doi.org/10.1080/09603100210161965 